UDK $60 / 63$

GLASILO

FUTURE

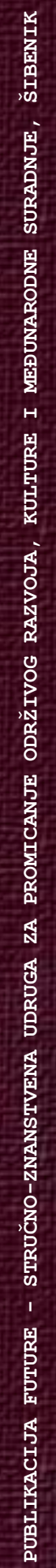

VOLUMEN 1 BROJ $1-2$

LIPANJ 2018.
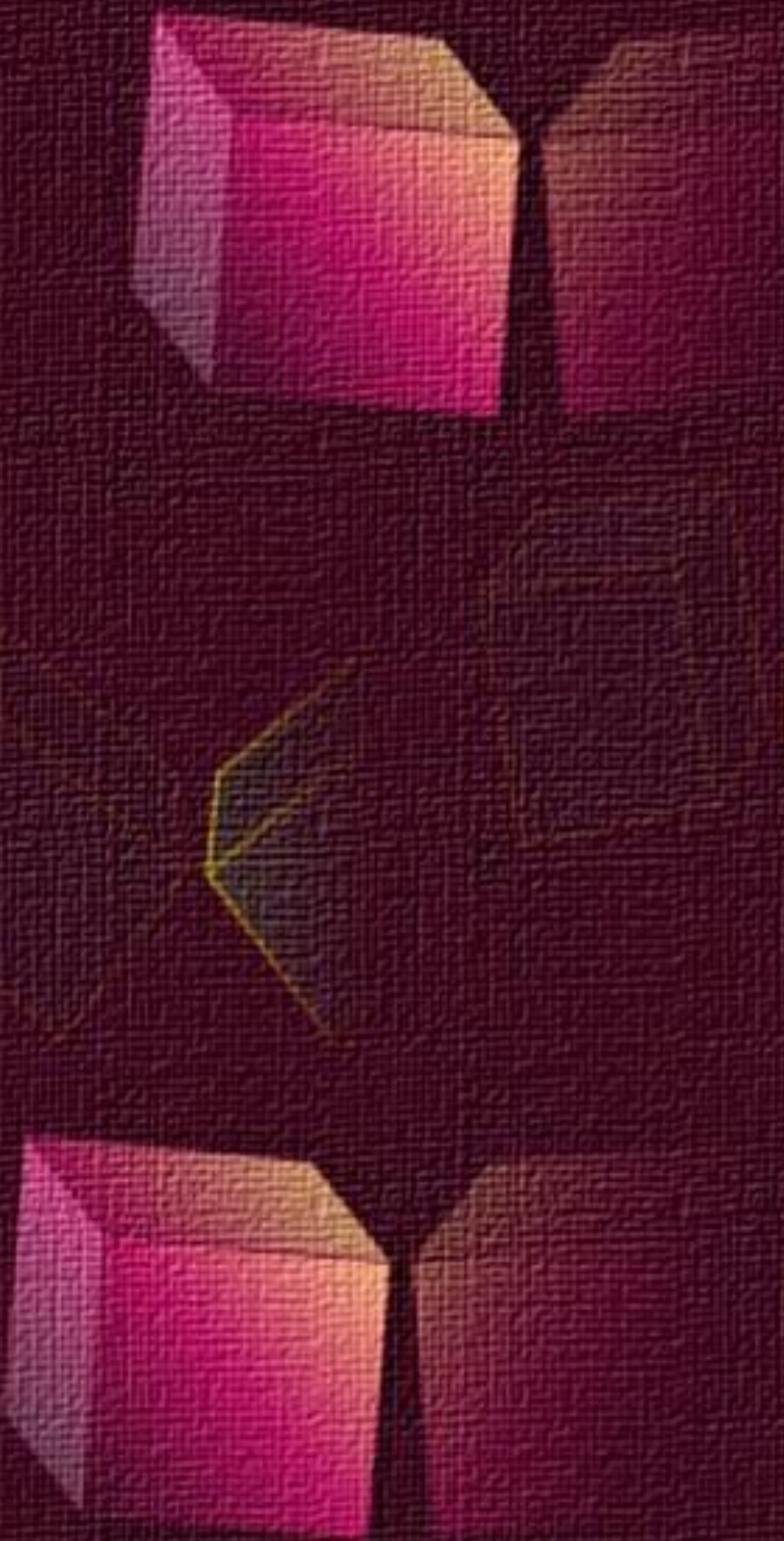


\section{Glasilo Future}

\section{Stručno-znanstveni časopis}

Nakladnik:

Futura

\section{$F_{\mathrm{UT}}^{\mathrm{T} T \mathrm{TR}} \mathrm{A}$}

Sjedište udruge: Šibenik

\section{Adresa uredništva:}

Bana Josipa Jelačića 13 a, 22000 Šibenik, Hrvatska / Croatia 留 / 且: +385 (0) 022218133

\: urednistvo@gazette-future.eu / editors@gazette-future.eu

(3): www.gazette-future.eu

\section{Uređivački odbor / Editorial Board:}

Doc. dr. sc. Boris Dorbić - glavni i odgovorni urednik / Editor-in-Chief

Emilija Friganović, dipl. ing. preh. teh., v. pred. - zamjenica g. i o. urednika / Deputy Editor-in-Chief

Ančica Sečan Matijaščić, univ. bacc. act. soc. - tehnička urednica / Technical Editor

Antonia Dorbić, mag. art - zamjenica tehničke urednice / Deputy Technical Editor

Prof. dr. sc. Željko Španjol

Mr. sc. Milivoj Blažević

Vesna Štibrić, dipl. ing. preh. teh.

\section{Međunarodno uredništvo / International Editorial Board:}

Prof. dr. sc. Kiril Bahcevandziev - Portugal (Instituto Politécnico de Coimbra)

Prof. dr. sc. Martin Bobinac - Srbija (Šumarski fakultet Beograd)

Doc. dr. sc. Zvezda Bogevska - Makedonija (Fakultet za zemjodelski nauki i hrana Skopje)

Dario Bognolo, mag. ing. - Hrvatska (Veleučilište u Rijeci)

Prof. dr. sc. Agata Cieszewska - Poljska (Szkoła Główna Gospodarstwa Wiejskiego w Warszawie)

Prof. dr. Bogdan Cvjetković, prof. emeritus - Hrvatska (Agronomski fakultet Zagreb)

Doc. dr. sc. Margarita Davitkovska - Makedonija (Fakultet za zemjodelski nauki i hrana Skopje)

Prof. dr. sc. Semina Hadžiabulić - Bosna i Hercegovina (Agromediteranski fakultet Mostar)

Prof. dr. sc. Péter Honfi - Mađarska (Faculty of Horticultural Science Budapest)

Prof. dr. sc. Valeria Ivanova - Bugarska (Fakultet za lozaro - gradinarstvo Plovdiv)

Doc. dr. sc. Orhan Jašić - Bosna i Hercegovina (Filozofski fakultet Tuzla)

Prof. dr. sc. Biljana Lazović - Crna Gora (Biotehnički fakultet Podgorica)

Hrv. akademik prof. dr. sc. Stanislav Nakić - Bosna i Hercegovina (Sveučilište Hercegovina Mostar)

Sandra Popović, mag. ing. - Srbija (Poljoprivredni fakultet Zemun)

Doc. dr. sc. Bojan Simovski - Makedonija (Šumarski fakultet Skopje)

Prof. dr. sc. Davor Skejić - Hrvatska (Građevinski fakultet Zagreb)

Doc. dr. sc. Milan Stanković - Srbija (Univerzitet u Kragujevcu)

Prof. dr. sc. Andrej Šušek - Slovenija (Fakulteta za kmetijstvo in biosistemske vede Maribor)

Prof. dr. sc. Elma Temim - Bosna i Hercegovina (Agromediteranski fakultet Mostar)

Doc. dr. sc. Ivana Vitasović Kosić - Hrvatska (Agronomski fakultet Zagreb)

Doc. dr. sc. Ana Vujošević - Srbija (Poljoprivredni fakultet Zemun)

Prof. dr. sc. Vesna Židovec - Hrvatska (Agronomski fakultet Zagreb)

Grafička priprema: Ančica Sečan Matijaščić.

Objavljeno 30. lipnja 2018. godine.

Časopis izlazi u elektroničkom izdanju dva puta godišnje, krajem lipnja i prosinca, a predviđena su i dva interdisciplinarna specijalna izdanja tijekom godine iz STEM i ostalih znanstvenih/umjetničkih područja. Časopis je besplatan.

Rukopisi i recenzije se ne vraćaju i ne honoriraju.

Umnožavanje (reproduciranje), stavljanje u promet (distribuiranje), priopćavanje javnosti, stavljanje na raspolaganje javnosti odnosno prerada u bilo kojem obliku nije dopuštena bez pismenog dopuštenja Nakladnika. Sadržaj objavljen u Glasilu Future može se slobodno koristiti u osobne i obrazovne svrhe uz obvezno navođenje izvora. 


\section{Glasilo Future}

\section{Stručno-znanstveni časopis}

FUTURA - stručno-znanstvena udruga za promicanje održivog razvoja, kulture i međunarodne suradnje, Bana Josipa Jelačića 13 a, 22000 Šibenik, Hrvatska

(2018) $1(1-2) 01-64$

\section{SADRŽAJ:}

Izvorni znanstveni članak (original scientific paper)

\section{Ivana Vitasović-Kosić}

Tradicionalna upotreba samoniklog jestivog bilja na području općine Kršan (Istra, Hrvatska)

Traditional wild food plants used in Kršan municipality (Istria, Croatia)

\section{Prethodno priopćenje (preliminary communication)}

\section{Blažević}

Crtice iz povijesti poljoprivrede, šumarstva i hortikulture Šibenika (1774.-1941.)

Short review from history of agriculture, forestry and horticulture of Šibenik (1774-1941)

B. Dorbić, Marija Lizatović, Ivna Podrug

Percepcije o ukrasnim vrijednostima i primjeni palmi na Mediteranu

Perceptions of decorative values and application of palms in the Mediterranean

Pregledni rad (scientific review)

\section{Ela Brkić, Nikolina Gaćina}

Stevia rebaudiana Bertoni - prirodni funkcionalni zaslađivač

Stevia rebaudiana Bertoni - natural functional sweetener

\section{Stručni rad (professional paper)}

Emilija Friganović, Katarina Bilić, Mladenka Šarolić, B. Dorbić

Energetske vrijednosti i količina hranjivih tvari odabranih slastičarskih proizvoda

Energy value and the amounts of nutrients of selected pastry products

\section{Nekategorizirani rad (uncategorised paper)}

Zdenka Bilušić, B. Dorbić

Prikaz konferencije

Review of conference

Zdenka Bilušić

Prikaz izložbe

Review of exhibition 


\title{
Crtice iz povijesti poljoprivrede, šumarstva i hortikulture Šibenika (1774.-1941.)
}

Short review from history of agriculture, forestry and horticulture of Šibenik (1774-1941)

\section{Milivoj Blažević ${ }^{*}$}

prethodno priopćenje (preliminary communication)

\section{Sažetak}

Poljodjelstvo, hortikultura, uređenje krajobraza i šumarstvo je tematika koja se u posljednje vrijeme vrlo malo obrađivala u sklopu povijesnih i socijalno-gospodarskih aspekata. Na šibenskom području poljoprivreda je bila važno gospodarsko zanimanje i u međuratnom razdoblju od 1918.-1941. godine. Za vremena ubrzanijeg razvitka industrije, poljoprivreda šibenskog područja bila je pretežno utemeljena na uzgoju vinove loze i masline i ponešto povrća. Problemi slabo educiranog stanovništva za moderni način poljoprivredne proizvodnje nisu dopuštali da se ova grana gospodarstva adekvatno razvije. U radu se prikazao jedan širi spektar vrijednosti ovih pojedinosti u općoj kulturnoj i edukativnoj slici grada Šibenika. Poljodjelstvo, parkovno uređenje, hortikultura i šumarstvo bilo je od izuzetnog značaja za globalnu sliku o gradu Šibeniku. Učinak tih djelatnosti bilo je od značajne važnosti za preobrazbu Šibenika iz ruralnog u urbano središte. Doprinosi ovih djelatnosti kroz iznesene podatke prikazuje obilje zavičajnih podataka iz različitih vremenskih razdoblja, a koje svoju izravnost izvlače iz gradske i težačke sredine i običaja ovog podneblja. Ovaj kratki prikaz samo je dio doprinosa za daljnje proučavanje bogate baštine šibenskog gospodarstva i promicanja simbioze građanske uljudnosti.

Ključne riječi: Poljodjelstvo, hortikultura i šumarstvo, crtice, povijest, Šibenik.

\begin{abstract}
Agriculture, horticulture, landscaping and forestry are topics that have recently been insufficiently addressed from historical, social and economic aspects. In the region of Šibenik agriculture was an important branch of the economy and occupation in the interwar period from 1918 to 1941. During more accelerated industrial development, agriculture in the region of Šibenik was primarily based on grapevine cultivation, as well as on planting of olive trees and several vegetable species. Problems linked with insufficient education of the population concerning modern agricultural methods prevented adequate development of this branch of the economy. The paper presents a wide range of values of these specific features of the city of Šibenik from the general, cultural and educational aspect. Agriculture, park landscaping, horticulture and forestry have been extremely important for the
\end{abstract}

\footnotetext{
${ }^{1}$ Mr. sc. Milivoj Blažević, 8. dalmatinske udarne brigade 20, 22000 Šibenik-Hrvatska.

*Email: milivoj.blazevic@gmail.com.
} 
overall image of the city of Šibenik. The impact of these activities has been highly significant for the transformation of Šibenik from a rural into an urban centre. The impact of these activities shown through provided information presents a comprehensive insight on our region dating back to different periods of time, whose directness is the result of both urban and rural milieu and the customs typical of this region. This brief overview provides an incentive for further studies of the rich heritage of Šibenik economy and strives to promote the symbiosis of civic politeness.

Key words: agriculture, horticulture and forestry, sketch history, Šibenik.

\section{Uvod}

Poljodjelstvo, hortikultura, uređenje parkova i vrtova te šumarstvo je tematika koja se do današnjih dana vrlo malo obrađivala $\mathrm{s}$ povijesnih i socijalno-gospodarskih aspekata. U novije vrijeme iz navedenog su dani izuzetno vrijedni znanstveni doprinosi (Blažević, 2007; Dorbić, Pamuković i Blažević, 2014; Dorbić i Temim, 2016; Dorbić i Temim, 2016; Dorbić, Pamuković i Blažević, 2017). u cilju obogaćivanja lokalnog i regionalnog znanstvenog fundusa iz navedenog stručno-znanstveno područja.

Važno je napomenuti da je početkom 20. stoljeća započela propast vinogradarstva i masovno iseljavanje stanovništva iz Dalmacije (Defilippis, 2006).

Štetnik vinove loze (filoksera) je uvjetovao da dio vinograda bude zapušten sve do početka obnove istih, 1904. godine, kada je austrijska vlast podržavala kreditnu dugoročnu obnovu u vinogradarstvu. To je potrajalo sve do 1910. godine (Dorbić et al., 2017). ${ }^{2}$

Poljoprivreda je bila važno gospodarsko zanimanje velikog broja građana Šibenika i njegove okolice međuratnom razdoblju od 1918.-1941. godine. U razdoblju kada se razvija industrija, poljoprivreda šibenskog kraja bila je pretežno utemeljena na uzgoju vinove loze i masline, a djelomično i na povrćarstvu. Problemi slabo educiranog stanovništva za moderni način poljoprivredne proizvodnje nisu dopuštali da se ova grana gospodarstva adekvatno razvije (Blažević, 2007, prema Dorbić et al., 2017).

Kad se govori o važnost i značaju lokalne poljoprivredne proizvodnje, a ponešto i o kulturološkoj tradiciji parkovne kulture grada Šibenika i njegovog šireg zaleđa, a to je zaleđe nosilac raznolike stvarnosti u krajobrazu koji u modernom vremenu omogućava realizaciju novih rezultata na razvoju prepoznatljivih komponenti turističkog razvoja ovog podneblja. U radu se.nastojao prikazati jedan širi spektar vrijednosti ovih specifičnosti u općoj kulturnoj i edukativnoj slici grada Šibenika. Stoga se interes za ovu tematiku smatra nizanjem različitih pojavnosti kroz povijest grada i utjecaju kroz ove

\footnotetext{
${ }^{2}$ Više u Grubišić et al., (ur.). (1976.). Zbornik o 900-toj godini grada Šibenika. Muzej grada Šibenika.
} 
djelatnosti na širu kulturu, gospodarsku sferu i njen značaj u organiziranju urbanog tkiva od najranijih vremena do suvremenih komunalnih stremljenja. Korištenjem stručnih i znanstvenih izvora, arhivskih podataka i druge relevantne znanstvene literature te pojedinim komparacijama izdvojili su se podaci od osobite važnosti za Šibenik i njegov značaj u povijesti Dalmacije i Hrvatske.

\section{Povijesni prikaz do perioda hrvatskog narodnog preporoda}

Kako bi se objasnio ovaj razvoj potrebno je nešto reći o počecima organiziranog pokušaja vrtnog i krajobraznog uređenja, kako građansko-plemićkih stambenih objekata i posjeda, tako i ladanjskih imanja u široj gradskoj sredini i na otočnom djelu šibenskog prostora (Zlarin, Prvić, Murter, Primošten). U uzgoju bilja, hortikulturi i unapređenju poljoprivrede najviše se vodila diskusija u neformalnim obrazovnim krugovima naprednog građanskog sloja i djelu slobodarskog plemstva. Ono je u dihotomiji pomalo uspavane dalmatinske inicijative ipak od sredine 18. stoljeća sve više prihvaćalo ideje francuskog enciklopedijskog pokreta i novo otkrivenih prirodnih recentnih znanosti. Kako je Venecija kao izvorište kulturne i političke misli u Dalmaciji privlačila interes te nove intelektualne elite, to se osjetilo odmah nakon što je 1767. godine u Splitu osnovana Akademija, a potom u Zadru i Trogiru (Božić-Bužančić, 1993).

U Šibeniku je 1776. godine bio pokušaj da se osnuje poljoprivredna škola. Inicijativu su podržavali i određeni krugovi u Veneciji, međutim nije ipak došlo do navedene realizacije. Kako je ovaj kraj kroz dugi niz stoljeća poznat po proizvodnji kvalitetnog vina i maslinovog ulja, povrća, mediteranskog voća (smokva i višnja maraska), to je zacijelo ponukalo plemića Josipa Parčića da pokuša oko osnivanja te škole (Dorbić i Temim, 2016).

Obitelj Soppe-Papalli kroz šibenski ogranak velike familije bila je od toga vremena poznati proizvođač visoko kvalitetnog likera Marascina koji se izvozio diljem Dalmacije na prostoru Mletačke republike i prostora austrijske carevine. Kasnije je primat u toj proizvodnji od 30-ih godina 19. stoljeća postepeno preuzimao Zadar (obitelji Salghetti-Drioli i Vlahov).

Zatečeni kmetski odnosi - težak obrađivač na zemlji i plemić rentijaš, nisu omogućavali brži napredak u primjeni poljoprivrednih inovacija kako u tehnici obrade zemlje, tako i u pripravi i kvaliteti finalnog proizvoda. Dalmatinski čovjek, tako i ovaj s šibenskog područja, živio je svoju tradiciju u neinventivnoj primjeni modernizma koji je u ostalom dijelu Mediterana i Europe bližim prekomorskim talijanskim pokrajinama pokazivao zavidne rezultate. To je naročito evidentno u modernom uzgoju krumpira i rajčice te tehnologiji žitne prerade, kao i konzervaciji voća i povrća. Nije se mnogo uradilo na ovom planu niti do kraja francuske civilne i vojne uprave u Dalmaciji i Šibeniku od 1806.-1814. godine (Peričić, 2016).

Dalmatinski guverner Vincenzo Dandolo pokušao je svojim gospodarskim reformama i uz pomoć poticaja francuskih vlasti pokrenuti lokalno gospodarstvo, računajući na veće mogućnosti u Dalmaciji. 
Postignuti su izvjesni rezultati u reformi pravosuđa, uprave, zdravstva i školstva, potom u zaštiti šuma i poboljšanju prometne infrastrukture, krajobraza i poljoprivrednoj proizvodnji. Od njegova se vremena u Šibeniku udomaćio izraz Sacra Bosco za planiranu šumu drveća iste vrste. Prvi pokušaji izvođeni su osim u Šibeniku i bližoj okolici i na području Skradina, u okružju Zadra i u gradovima Južne Dalmacije. To je bio prvijenac u sadnji šuma na prostoru otprilike minimalno 20 do 100 gonjaja zemljišta (1 gonjaj iznosio je oko $853 \mathrm{~m}^{2}$ ). Osim drveća alepskog bora sađena je i česvina, planika i jela na višim područjima zagorsko-brdskog djela krševite Dalmacije. ${ }^{3}$

Glavna hortikulturna obilježja ogledavaju se kroz uređenja i održavanja vrtova-đardina bogatije gospode (Garagnin u Trogiru, Pinelli u Zadru, Divnić u Šibeniku) i vlastele dubrovačkog podneblja kojoj su vrtni prostori Villa rustica u ljetnikovcima bila utjeha u razbibrizi i razonodi, te promenadi glazbenih i kazališnih svečanosti. ${ }^{4}$

U Šibeniku je djelovao čitav niz uspješnih fiziokrata, možda i framasona u razdoblju potkraj 18. i početkom 19. stoljeća. Među njima su bili istaknuti članovi obitelji Draganić-Mihetić, obitelji Vidović $\mathrm{s}$ uređenim imanjem u Primoštenu, obitelji Giadorou kao vlasnici niza poljoprivrednih imanja $u$ najamnom odnosu na prostoru Grominjak neposredno u blizi zemljišta Oblić istočno od središta. Važno je istaknuti i rad Viktora Galiatovića i Vincenza Draga-Bucha, a u kasnije vrijeme za istaknuti je učenika Daniela Divnića koji je pisao i oglede o vinarstvu sredinom 19. stoljeća (1857. godine većina u rukopisu). Divnići su bili veliki zemljoposjednici u šibenskom polju i na području otoka Murtera (Slika 1. i 2.). Organizirana zaštita okoliša nije se mogla u potpunosti osigurati niti često donošenim lokalnim i pokrajinskim proglasima tipa Avviso i Nottificazione gdje se oglasima i uputama o vrstama i načinu posla pokušavalo preko nižeg klera i školovanijeg građanstva pripremati i podučavati veći dio neobrazovanog i nepismenog građanstva na svrhovitu i trajniju njegu u poljodjelstvu, vrtlarstvu i šumarstvu kao i primjeni tada recentne tehnologije.

Ipak se može reći da se stvari nisu mijenjale sve do razdoblja zadnje četvrtine 19. stoljeća. Tada je na vlast u gradu došla narodna uprava nacionalnog hrvatskog obilježja. Ona je počela s komunalnim normiranjem propisa i rješavanjem uredbi centralne vlasti u Zadru koje su se odnosile oko unapređenja poljoprivrede i šumarske službe, budući je upravo u to vrijeme izglasan i novi Zakon o šumama (od osobite važnosti za dalmatinsko seljaštvo).

\footnotetext{
${ }^{3}$ DAŠI, Fond Općinsko upraviteljstvo u Šibeniku (1813.-1918.).

${ }^{4}$ Ibid.
} 

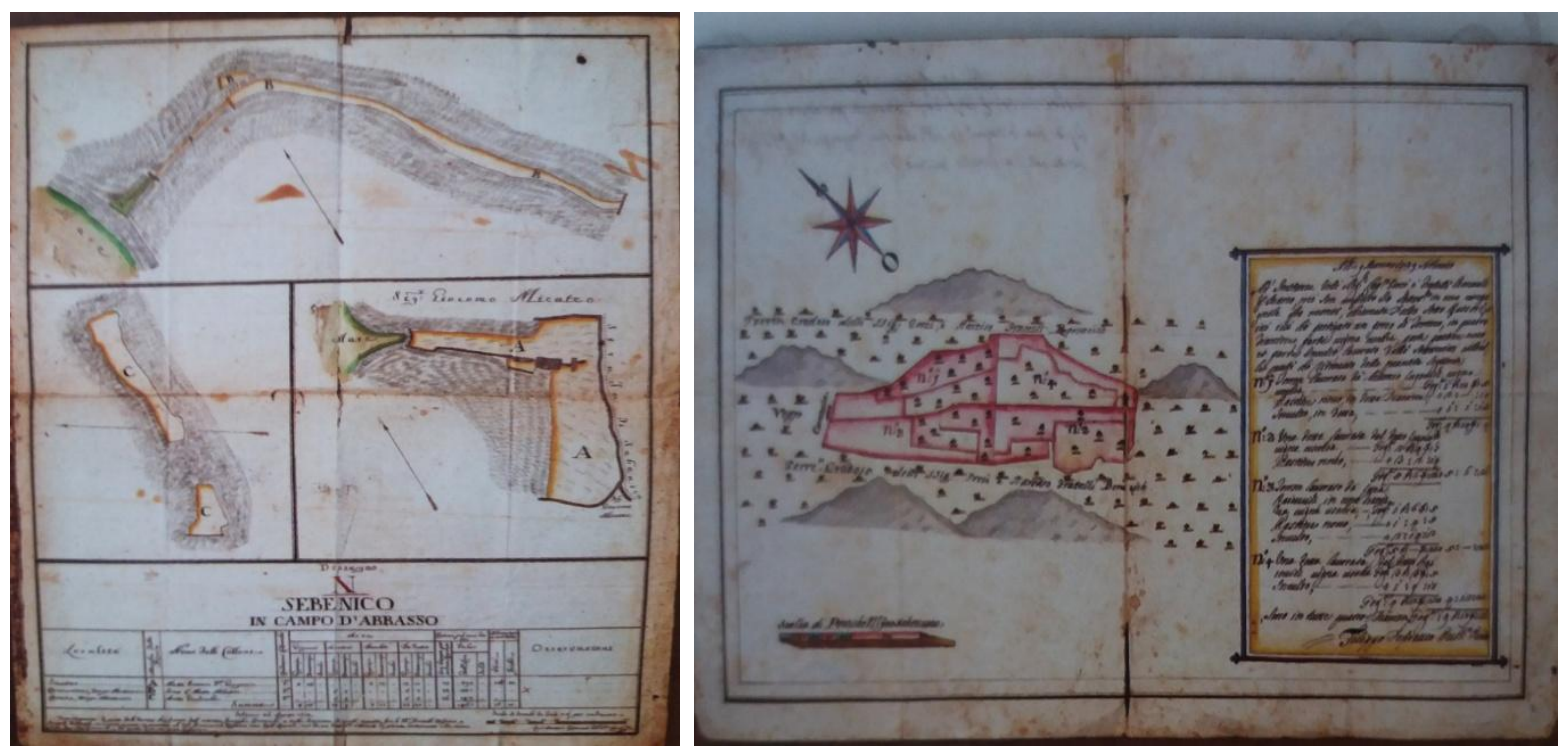

Slika 1. Donje polje 1812. godine, Fond obitelji Divnić (Difnico) (Blažević, 2011)

Figure 1. Donje Polje in 1812., Divnić Family Fund (Difnico) (Blažević, 2011)

Slika 2. Razor, 1739. godine, Fond obitelji Divnić (Difnico) (Blažević, 2011)

Figure 2. Razor in 1739., Divnić Family Fund (Difnico) (Blažević, 2011)

\section{Akcija pošumljavanja u Šibeniku i okolici}

Prvo pošumljavanje gradskih i prigradski zelenih površina i pustog krševitog brdskog prostora otpočelo je u Šibeniku od 1889. godine i to oko novo sagrađene željezničke stanice. Na tome se osobito isticao vrijedni gradski općinski vrtlar Marko Belamarić, koji je ujedno bio i prvi službenik za izvršavanje tih poslova. Na sjednicama gradskog vijeća tijekom 1889. godine u više navrata raspravljalo se o potrebi podizanja rasadnika šumskog i hortikulturnog bilja oko čega je značajne rezultate postigao općinski šumar Mate Baranović. Dokument br. 8539 nastao iz rada gradske uprave donosi podatak da je u Šibeniku tri godine ranije, dakle 1886. godine uspostavljen šumarski rasadnik. U spisu se donosi i podatak o troškovniku za akciju pošumljavanja Šibenika i njegove bliže okolice za razdoblje sve do 1896. godine. Mjeseca ožujka 1894. godine pregledavane su šumske površine na prostoru Zatona, Srime i Pakline kao i područja Zablaća. Željelo se pripremiti što više terena za nasad i održavanje novih šumskih vrsta. Prvo je pošumljen općinski pašnjak na Rupinama (danas dio šume na predjelu Šubićevac, neposredno u blizini grda, iznad gradskog predjela Varoš, te se prešlo na pošumljavanje goleti na potezu od Jamnjaka preko brda Šubićevac, sve do lokaliteta Rokić drage istočno od Varoša). U istoj godini pošumljavano je više pašnjaka, pa tako u Slivno-Perković, Vrpolju (Vrhpolje) i Jadrtovac (ex. Castel Andreis). Novčanu pomoć i stručnu izobrazbu za izvršitelje ovih poslova pripomogao je svojim sredstvima Zemaljski odbor Pokrajinskog sabora u Zadru. Od tada je počelo i vođenje šumskog katastra za cijeli grad i kotar Šibenik, budući je centralna vlast u Zadru odlučila da se od 1880. godine počinju voditi i zemljišne knjige pri općinskim sudovima u Dalmaciji. Pošumljavanje je obavljeno i na lokaciji Trovrh kod Slivna 1894. i 1895. godine, te potom i na lokaciji 
Kopar kod Rogoznice na površini od $52.849 \mathrm{~m}^{2}$. Na otoku Krapnju je pošumljena površina oko mjesnog samostana te na ostalom dijelu otoka u ukupnoj površini od 10 jutara. Za te je radnje Poglavarstvo grada Šibenika utrošilo 400 fiorina. Za ove radnje oko podizanja šumskih površina općinski inženjer je primio na dar od Poglavarstva grada Makarske $40 \mathrm{~kg}$ sjemena alepskog bora (Pinus halapensis Mill.).

Godine 1896. otpremljeno je iz Drniša u Šibenik preko općinskog šumara Nikole Vežića gotovo 12. tisuća sadnica podvrste crnoga bora (Pinus nigra var. Austriaco). Za tu je godinu u gradu iz općinske blagajne bilo predviđeno 700 fiorina za unapređenje Šumarstva. Općinski rasadnik bio je u funkciji i 1892. godine, budući je za pošumljavanje osigurano 550 sadnica vrste Cedrus deodara, 8 kom Cedrus libanonica, 74 kom bajame Prunus amygdalus, 0,50 kg sjemena Cupressus sempervirens var. Pyramidalis, $10 \mathrm{~kg}$ sjemena Abies pinsapi, $15 \mathrm{~kg}$ sjemena Pinus pinaster, $30 \mathrm{~kg}$ sjemena Pinus halapensis. Na ovim poslovima izuzetne su zasluge članova šibenskih obitelji: Baranović, Šupe, Blaće, Brkić i Stošić. Najveće područje pošumljavanje izvršeno je na goleti izvan grada prema Donjem polju, zatim prema Bilicama i djelom na padinama brda ispod šibenskog Varoša, kao i na širem prostoru Ražina. Zanimljiv je sačuvani podatak da je za tu prigodu šibenski težak Nikola Takelja pribavio 10 tovara domaćeg gnojiva, što kristalno tumači probuđenu ekološku svijest domicilnog pučanstva. $^{5}$

Tek se 10 godina nakon filoksere i drugih bolesti na vinovoj lozi počinje u Šibeniku intenzivnije pošumljavati krška područja Srime, kanala Sv. Ante i širi istočni prostor grada. Pošumljavalo se i na području od Bilica preko Dubrave i sve do Danila, a sjevernije i na širem prostoru oko Lozovca i Konjevrata. Kroz čitavo 19. stoljeće, pa tako i početkom 20. stoljeća, šibenski težak sadi koštelu, bajamu i gradsku smokvu tzv. petrovku. Nova urbanistička rješenja izvan gradske jezgre traže obradu ivičnjaka i vrtova obiteljskih kuća na prostoru Varoša, Plišca i oko zgrade nove Pokrajinske bolnice nakon 1883. godine (Slika 3.). Prethodno je na širokom prostoru bolnice od sredine 19. stoljeća bila uređena šuma, vrtovi i odmaralište obitelji Kovačević što je bilo dokono mjesto građanskog Šibenika cijelog vremena. ${ }^{6}$

Pošumljavanje prostora uz tvrđave Sv. Mihovil i Sv. Ivan te tvrđavu Barone otpočelo je u ovom vremenu. Sjevernoistočna strana brda podno tvrđave Sv. Mihovila imenovana je kao Mrkičin gaj, budući je kanonik i dobrotvor don. Josip Mrkica pokazivao izuzetno zalaganje za uređenje okoliša.

\footnotetext{
${ }^{5}$ Blažević, M. Razni zapisi i podaci iz šibenske povijesti, u rukopisu.

${ }^{6}$ Ibid.
} 


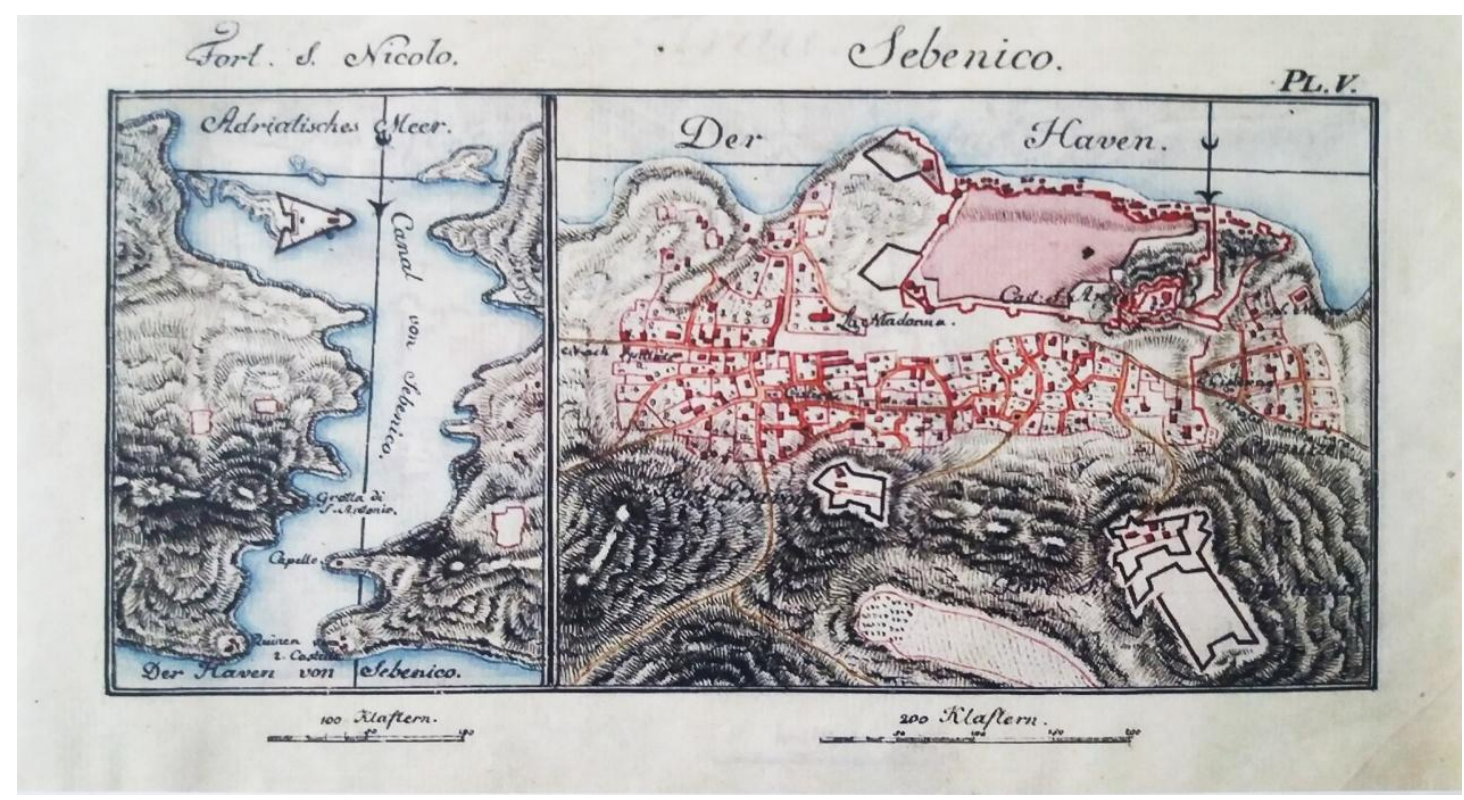

Slika 3. Urbani vrtovi na području grada Šibenika iz 1805. godine (Žmegač, 2016).

Figure 3. Urban gardens in the city of Šibenik from 1805. (Žmegač, 2016).

\section{Počeci krajobraznog uređenja u Šibeniku}

Neuređeni prostor uz istočni bedem u Šibeniku na potezu od Poljane do Porporele u pristaništu, bio je od velike zanimacije općinskih vlasti od 1895. godine od kada počinje uređenje gradskog perivoja, po tzv. talijanskom geometrijskom uzoru (Dorbić, Pamuković i Blažević, 2014).

Znanstvenica šibenskih korijena gosp. dr. Jagoda Marković je prigodno u svojoj doktorskoj disertaciji o šibenskom urbanizmu ovog razdoblja prikazala položaj i nastanak tog gradskog perivoja. Općina je ugovorila dovršetak perivoja za 12,000 fiorina, a arhitektonske elemente kreirao je istaknuti brački klesar Andrija Orlandini. Od 1894. godine postavljene su i fontane nabavljene preko firme Juhazs iz Graza. Uređen je i središnji parkovni vodoskok fontane s ribnjakom. Tlocrtna shema ocrtava ortogonalni raster šetnica, koje zauzimaju polovicu ukupne površine parka s naglašenim cvjetnim rondelama u središnjoj osi, kako ističe gosp. dr. Marković (Marković, 2009).

U centralnom prostoru donjeg dijela perivoja postavljen je i 31.05.1896. godine spomenik Nikoli Tommaseu, piscu, pjesniku i lingvisti europskog profila, rođenog u Šibeniku, 1802. godine s posljednjim počivalištem u Settignanu pokraj Firence 1874. godine (Slika 4.). Naš je slavni Šibenčanin imao veliki upliv na romantički dio hrvatske kulture i književnosti, kao i veliki doprinos novoj talijanskoj jezičnoj komponenti 19. stoljeća.

Park ispod Gospe van grada, nasuprot šibenske Poljane podignut je nakon 1923. godine na preuređenom prostoru bivšeg groblja-šematorija. Taj je park stilski oponašao većinu tlocrtnih obrazaca prvog šibenskog perivoja. Park šuma Šubićevac u nastajanju je neposredno po osnivanju istoimenog društva, a elementi tog tzv. slobodnog parka u prirodnoj osnovi, ponešto je asocirao na engleski 
pejsažni stil oblikovanja, ali svakako da je takav stil u engleskoj bez krša koji je ipak imanentan park šumama širom Dalmacije, pa tako i u Šibeniku. Ovdje je jedno vrijeme djelovao i zoološki vrt s nekoliko vrsta životinja, a neposredno iznad Rupina (lokalitet prvog izvorišta vode iz 1806. godine). Uređena je i sve do današnjih dana sačuvana tzv. Vidilica kao panoramsko odmorište na rubu šume na Šubićevcu.

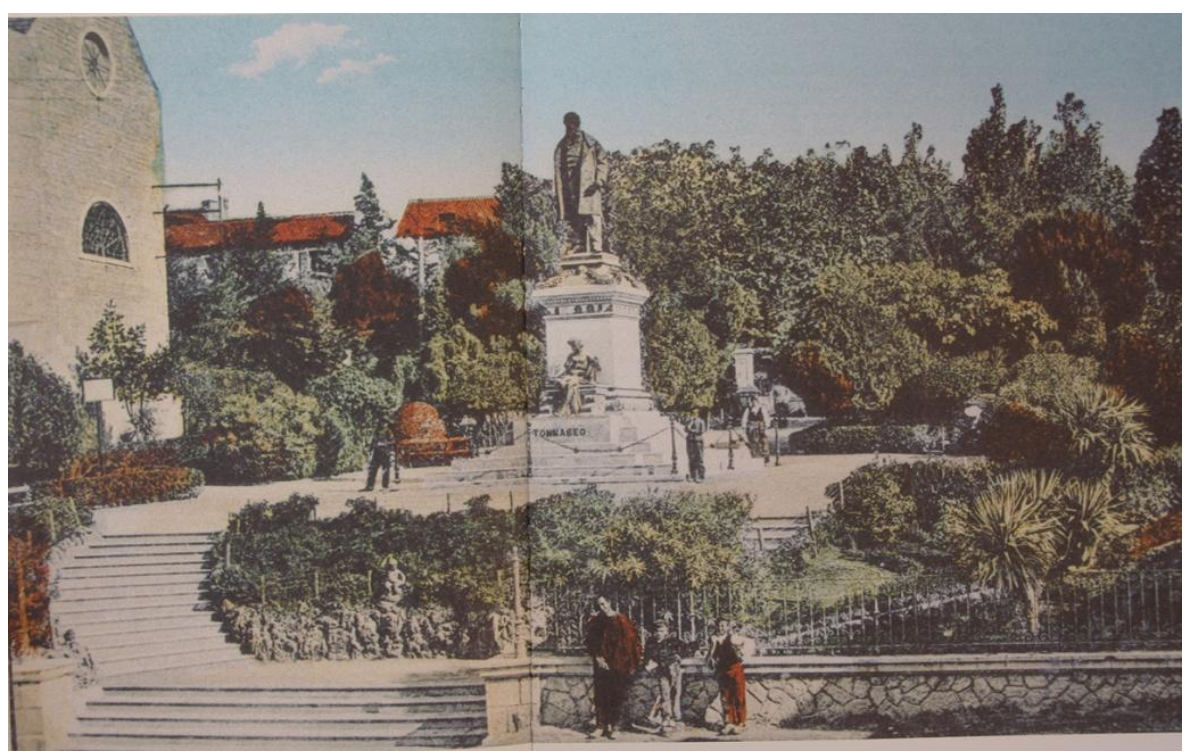

Slika 4. Perivoj Roberta Visianija u Šibeniku (Marković, 2009)

Figure 4. Park of Robert Visiani in Šibenik (Marković, 2009)

\section{Edukativni počeci u razdoblju gospodarskog poleta u Šibeniku}

Značajni infrastrukturni objekt koji je u znatnoj mjeri utjecao na promjene u gospodarstvu i socijalnom životu Šibenika, bio je cjeloviti vodovodni sustav Krka-Šibenik, čija je izgradnja započeta 1878. godine i dovršena do 20. svibnja 1879. godine. Kasnije je pred Veliki rat 1914. godine dodatno rekonstruiran, te je grad Šibenik dobio crpni kapacitet od 171 u sekundi, što je bilo dostatno za grad oko 15.000 pučana. Drugi je projekt bio cjeloviti energetski sustav proizvodnje, distribucije i potrošnje električne energije upotrebom vodnog resursa rijeke Krke kojeg su poduzeli agilni gradonačelnik Ante Šupuk i ing. Vjekoslav Meichsner. Grad je 28. kolovoza 1896. godine kao drugo mjesto u Europi dobio električnu energiju iz sustava izmjenične struje. To su bile godine kada Šibenik pomalo urbanizira svoje gradsko komunalno tkivo, a u gospodarskoj djelatnosti pronalazi izvorište za recentna dostignuća. Jedino je poljodjelska proizvodnja, osim vinarstva i maslinarstva bila u djelomičnom zaostajanju, ali takova je bila i opća slika stanja na prostoru čitave Dalmacije i drugih krajeva Hrvatske. Unatoč ulaganjima u pomorski sektor ipak je zbog nedostatka putnih pravaca i ne postajanja cjelovite željezničke veze prema sjeveru Hrvatske, Bosni i Hercegovini i austrijskim pokrajinama poljoprivreda je još uvijek bila ne konkurentna rezultatima i utjecaju modernog europskog svijeta. Nepostajanje domaćeg kapitala i bankarskog sustava kao i stoljetna nepokretnost seljačkog svijeta te nedostatak bolje edukacije uvjetovalo je sporo povećavanje i plasman poljoprivrednog viška i 
konkurentnost, premda je Šibenik u vinskoj proizvodnji držao primat u Dalmaciji sve do 1941. godine (Blažević, 2007).

I to je jedan od razloga da se u cilju povećanja poljoprivredne proizvodnje još od ranijeg perioda nakon 1873. godine započelo sa stručnom poljodjelskom izobrazbom. Na Nižoj dvorazrednoj gimnaziji općinska vlast je 1873. godine tražila pokretanje građanske škole sa stručnim ratarskim zanimanjem. Razlozi se nalaze u nezainteresiranosti šibenskih težaka oko školovanja vlastite djece, ako to nisu bila isključivo zanimanja koja bi ih zadržala na ovom podneblju. Nastava je započela sa ukupno 28 sati tjedno uz praktičnu vježbu. Od 1879. godine kod crkve Sv. Martina formiran je vrt iz vlasništva samostana Sv. Lovro, radi stručnih vježbi polaznika u poljodjelstvu. Ta je škola radila kao tečaj do 1881. godine uz kontrolu i nastavu učitelja-agronoma. Nastava je održavana kroz različite tečajeve sve do 1909. godine kada je dvo razredna gimnazija reformirana na viši četverogodišnji stupanj (Tambača, 1998).

Kotarski agronom Petar Bianchini Mastličević pokušavao je s naprednim gospodarskim glasilom pod nazivom Gospodarski poučnik. Taj prvijenac za poljoprivredu u Šibeniku je izlazio 2 puta mjesečno na četiri stranice i u to vrijeme imao je oko 100 pretplatnika. Taj je poljoprivredni časopis imao za cilj edukaciju gradskog težaka, te je za ono vrijeme pratio recentne novosti u domeni obrade tla i sadnje različitog kultiviranog bilja na obradivim površinama. Kasnije je edukacijsku službu preuzeo čitav niz mlađih stručnjaka koji su polagali stručne ispite na austrijskim učilištima (Dorbić i Temim, 2016).

To nas podsjeća na ona pionirska vremena poljoprivredne edukacije 1780.-1814. godine, kada su se ponajviše u Veneciji i Padovi objavljivali kraći gospodarski traktati lokalnih spisatelja iz Splita, Zadra, Trogira i Dubrovnika. Većinom su to bili radovi s ciljem propagande intenziviranja biljne proizvodnje (krumpir, pšenica, raž, vinova loza, maslina, razno mediteransko voće, dudov svilac, bajama, glatki kukuruz cikvantin, rajčica, dud itd.) (Božić-Bužančić, 1993). U Šibeniku se 1816. godine pojavio oglas vezan uz promet i trgovinu napolitanske pomorske flote s uputama o novoj tehnologiji kalemljenja tj. cijepljenja bajame. Naj poznatiji promotor edukacije pučanstva bio je do sredine 19 . stoljeća, civilno-vojni upravitelj Dalmacije Veter von Lilienberg. Promovira se tehnologija načina priprave crnog vina prema načelima iz Bordauxa u Francuskoj. Za težake je i uputa o izradi novog kara (drvena zaprežna kola na četiri kotača s konjskom zapregom), a sve prema talijanskoj tehnologiji iz 1823.-1825. godine. Do toga vremena dvokolna ulična kariola bila je sredstvo gradskog i prigradskog težačkog prometovanja. Popularni šibenski drveni kar bio je u upotrebi sve do kraja 20. stoljeća kada je izgubio bitku s novim sredstvima prometovanja. Snažniji razvoj svih poljodjelskih 
djelatnosti vidljiv je nakon osnivanja Vinarskog društva 25. 08. 1872. godine i djelovanja Kotarske poljoprivredne službe (Slika 5. i 6.). ${ }^{7}$
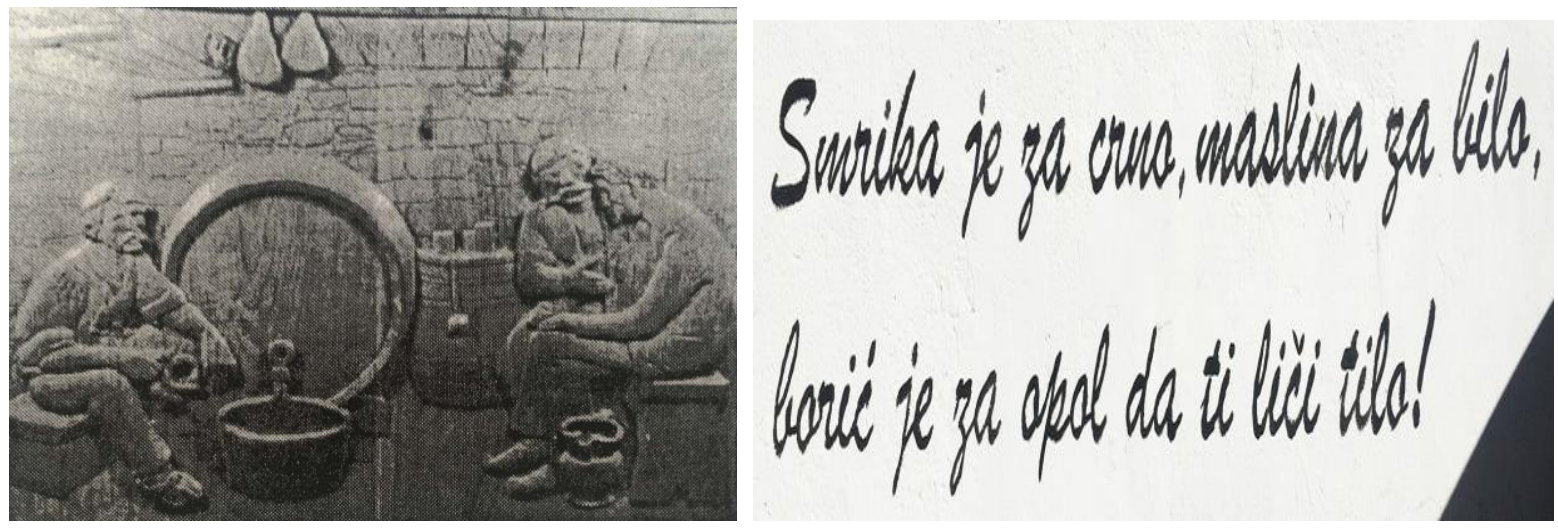

Slika 5. Šibenska konoba, duborez majstora Ante Belamarića (Tambača, 1998)

Figure 5. Šibenik tavern, woodworks by master Ante Belamarić (Tambača, 1998)

Slika 6. Oslikani dio zidnog grafita pokraj zgrade Športske dvorane "Partizan" u šibenskom predjelu Miminac, 2016. godine (Foto: Boris Dorbić, 2016)

Figure 6. Painted part of the wall graffiti next to the building of the Partizan Sports Hall in the Sibenik area of Miminac, 2016 (Photo: Boris Dorbić, 2016)

\section{Ukorijenjenost šibenske tradicije}

Gotovo je nevjerojatno s koliko su ljubavi i pozornosti građani Šibenika učestvovali u raznim crkvenim i svjetovnim svečanostima i prigodarsko-trivijalnim obljetnicama. Naime to se očitovalo u primjeni različitih oblika pripravaka ukrasnih cvjetnih aranžmana i raznolikog bilja, pogotovo pri proslavi tijelova, gradskih svetkovina u srpnju mjesecu i Božića. Gotovo svake godine brojno je pučanstvo učestvovalo u više dnevnim carskim obljetnicama kada je grad na mjestima glavnih prometnica, uz veće crkvene objekte, pogotovo na obalnom platou oko katedrale i stolne crkve blistao od mnoštva, girlandi, palminih grana i cjelovitih aranžmana. Nije bez razloga da je u Šibeniku sve do kraja 19. stoljeća postojao običaj nagrađivanja uređenja balkona i prozorskih okna koji su slikovito kićeni pretežno u proljetnim danima. Tada je gradska uprava normirala jedan službeni oglas o obilježavanju u trgovačkom prometu, na način da je reklamu za označavanje trgovine verdure-povrće i drugih poljoprivrednih proizvoda dozvoljavala bojadisanjem kamenog nadvratnika na ulaznim vratima. Radilo se to od 1833. godine nanošenjem zelene boje na gornji iskošeni dio i smeđe na vanjskoj površini nadvratnika. ${ }^{8}$

Sajmovni dani u Skradinu, Zatonu, Drnišu, Vrpolju i drugim mjestima bili su ne samo vjerskog značaja nego i jedinog mjesta veletrgovine poljoprivrednim i zanatskim viškom. Koliko je poljodjelstvo u središtu zanimanja svjedoče i posjete Šibenčana tradicionalnim sajmovima u Senegaliji

\footnotetext{
${ }^{7}$ Blažević, M, Razni podaci iz šibenske prošlosti, u rukopisu., Državni arhiv u Šibeniku (dalje DAŠI), Općinsko upraviteljstvo (1813.-1918).

${ }^{8}$ DAŠI, Općinsko upraviteljstvo (1813.-1918. godine.).
} 
blizu Ancone koji su se kroz 15 dana održavali svake godine od početka srpnja mjeseca. Ne smije se zaboraviti niti podatak da je u Šibeniku ostao do danas očuvan tradicionalni dan tzv. Proslave, koja se svake godine na 17. prosinca slavila kao poravnanje zimskog solsticija i u čast nadolazećeg Božića, a čiji korijeni proslave potijeću iz pradavne hrvatske povijesti. Nigdje, osim u Šibeniku nije se ta tradicija toliko dugo i brižno očuvala, jednako kao i onaj uobičajeniji težački poljski razgovor kojeg su Dolačani, Goričani i Varošani znali obavljati tijekom proljeća svake godine. U narodu je ostao kao izričaj razgovora s lozom gdje težak u polju ponavlja određene mantre prema poljoprivrednim kulturama kao bi utjecao na vjeru u održavanje, rast i očekivani prinos. ${ }^{9}$ To je zaista specifičan dokaz postojanja jedne u Europi ne zabilježene etnografske specifičnosti gdje tradicija nematerijalne kulture u izravnom odnosu čovjeka i prirode čini jedinstvenu simbiozu.

O počecima hortikulturne baštine na ovom području svjedoče dosada nepoznati podaci. Uzorite vrtne bašte i odmarališta kako u Šibeniku tako i na širem obalnom pojasu i otocima imale su pojedine bogatije plemićke i trgovačke obitelji. Divnići su od 15.-19. stoljeća posjedovali 11 takovih vrtova, dok je običan puk u prigradskom Varošu imao u ogradama obične vrtove za uzgoj povrća pa se to područje u lokalnoj kartografiji bilježi pod nazivom Vrtline. Uređeni prostori su vidljivi na sačuvanim kartama skicama i nacrtima zemljišnih posjeda, posebno onih o uređenoj podjeli i parceliziranju imanja na poljima Murtera i Betine, sačuvanih u arhivskoj ostavštini obitelji Divnić (Difnico). Od ladanjskih vrtova sačuvani su u gabaridima Vrančić-Draganić vrtovi u Prvić Šepurini s prikladno uređenim gospodarskim zgradama i ulaznoj aleji renesanskog tipa. Na Zlarinu su to ostaci vrta pokraj obiteljskih kuća Acalin i vile za odmor imućne obitelji Mazzoleni s početka 20. stoljeća. U Skradinu su vrtovi obitelji Pini, Dudan i Marasović, a u Tijesnom su vrtove posjedovali obitelji Gelpi, Alborghetti, Banchetti i Raimondi. U Šibeniku od početka 19. stoljeća vrt ispred obiteljske zgrade imaju Inchiostri, a na Gorici i u gradskoj jezgri više je malih vrtova od kojih je osnovnu strukturu sačuvao vrt obitelji Divnić iznad lokaliteta Galera u neposrednoj sredini Benediktinskog samostana Sv. Luce. Izuzetno je vrijedan i danas preuređen vrt samostana Sv. Lovre na Gorici koji je po svojoj prikladnoj oblikovnoj strukturi i raznolikošću raznim ukrasnim i ljekovitim vrstama jedan od najljepših srednjovjekovnih vrtova na području Južne Hrvatske (Slika 7.). ${ }^{10}$

\footnotetext{
${ }^{9}$ Naime, tijekom proljetnih i ljetnih radova u polju težak bi kriomice u ranim jutarnjim satima razgovarao $\mathrm{s}$ lozama svog vinograda pozivajući ih da budu dobre, poslušne i zdrave kako bi ljetina bila izdašna. U dokonim večernjim satima često bi takve molitve među težacima bile predmet međusobnog ogovaranja ili prigodnih pošalica na račun izgovorenih riječi koji bi težaci o pojedinoj osobi međusobno izgovarali. Pogotovo je to bio običaj u starim šibenskim konobama (tovernama). Navedeno uporište doznao sam iz dugogodišnjeg poznanstva i suradnje s težacima Gorice, Varoša i Doca.

${ }^{10}$ DAŠI, Općinsko upraviteljstvo Šibenik (1921.-1941), DAŠI, Kotarska oblast Šibenik (1921.-1941), Blažević, M. (2011). Katalog izložbe o šibenskom zemljištu. DAŠI.
} 


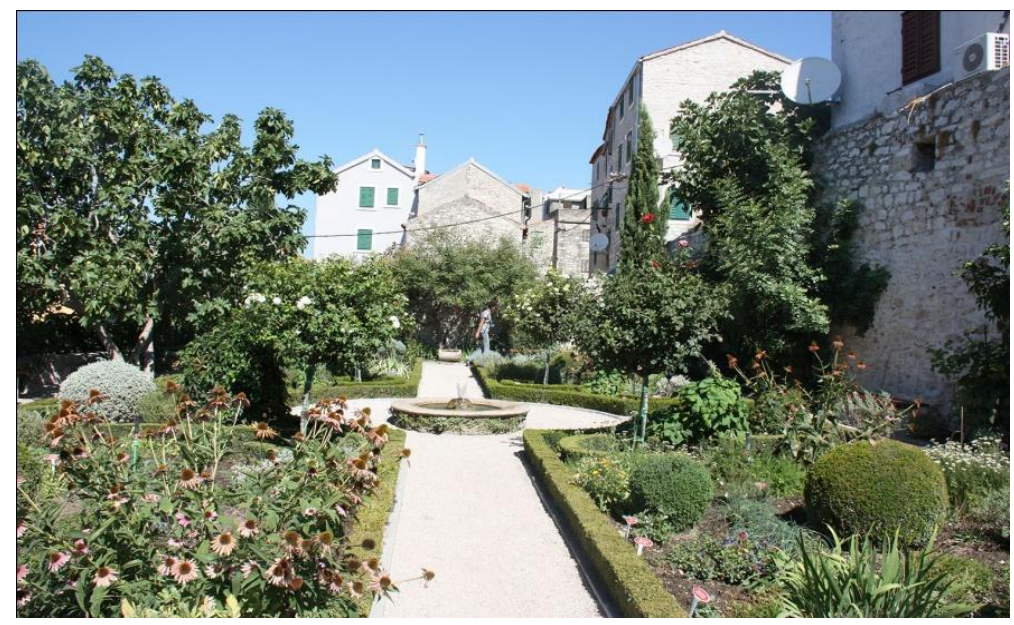

Slika 7. Mediteranski vrt Sv. Lovre u Šibeniku (Foto: Boris Dorbić, 2014)

Figure 7. Mediterranean garden Sv. Lovre in Šibenik (Photo: Boris Dorbić, 2014)

\section{Značaj istaknutih domaćih i stranih prirodoslovaca na području šibenika}

$\mathrm{Na}$ šibenskom području postojao je veći broj istinskih zaljubljenika koji su dio svog života poklonili unapređenju poljoprivredne djelatnosti, hortikulture, šumarstva i slično. Roberto Vissianiji koji je autor velikog prirodoslovnog djela Flora dalmatica (Ogled dalmatinskog bilja), uz to je djelovao i u Drnišu od 1830.-1835. godine, a kasnije i u Padovi. Može se nabrojiti i čitav niz zaslužnika kao što su ranije spomenuti: Petar Luka Bianckini-Mastličević, Nikola Vežić, šumarski djelatnik zaslužan za pošumljavanje Šubićevca, Perkovića-Slivno i Kanala Sv. Ante, Matu Baranovića, koji je gospodarskošumarske znanosti dovršio u Križevcima i 18. godina do 1905. godine djelovao u Šibeniku. Ozelenio je Paklinu i manje parkove u gradu. Gosp. Ante Frua, potomak istoimene talijanske obitelji doseljene iz Padove, osnivač je društva Šubićevac, koje je za primarni cilj imalo očuvanje gradske hortikulture, šumarstva i urbanog šumarstva (Slika 8.). Pošumio je područje oko Skradinskog buka uz rijeku Krku, šire područje Martinske te je bio i su osnivač gradskog kupališta i odmarališta Jadrija od 1922. godine. Osnivač je planinarskog društva Kamenar, čiji je bio dugogodišnji predsjednik i tajnik (Dorbić i Temim, 2016).

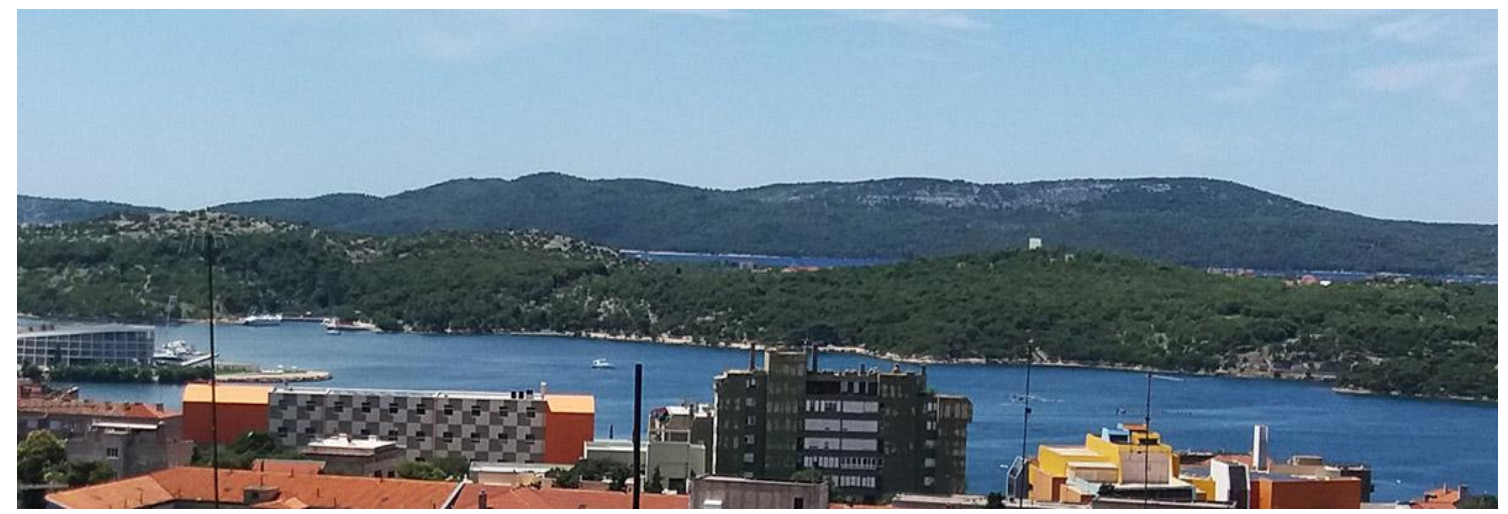

Slika 8. Paklina (Foto: Boris Dorbić, 2018)

Figure 8. Paklina (Photo: Boris Dorbić, 2018) 
Nikako se ne može zaobići i gosp. Vinko Anzulović, inženjer agronomije, koji je bio porijeklom s otoka Hvara, a sa službom u Šibeniku od 1904. godine. Djelovao je i na području Knina i Splita. Specijalnost mu je bilo vinarstvo i vinogradarstvo, ali je također zapažene rezultate imao osobito oko organiziranja različitih tečajeva u cilju unapređenja zaostalog voćarstva, vrtlarstva i maslinarstva. Bio je prepoznatljiv kao poljoprivredni edukator šibenskog težaka, a i za ostala mjesta oko Šibenik u razdoblju prve polovice 20. stoljeća. Do Velikoga rata djelovao je u unapređenju šumarstva i pokrajinski službenik ing. Štrekelj, koji je bio porijeklom iz Slovenije. Kod njega je Anzulović službovao praksu, a jednako tako je stjecao i potrebno iskustvo kod poznatog poljoprivrednog stručnjaka ing. Stanka Ožanića. Anzulović je odista bio edukator i učitelj velikog formata o čemu svjedoči i sačuvani službeni zapis korištenja literature i elemenata tijekom svoga djelovanja. $\mathrm{R}$ azna pravila, upute, izvještaji, knjige i brošure o poljoprivredi i hortikulturi, Zakoni o zadrugama, Glasnici, Ogledi uzgoja, razna opažanja, statistike i evidencije su djela koja sačinjavaju skupinu od gotovo 300 stotine stručnih publikacija iz kojih je kroz provođenje prakse na šibenskom području isti djelovao do 1941. godine. Provodio je educiranje od Rogoznice do Murtera, te od Šibenika pa do Knina (Dorbić et al., 2017).

Poljoprivredno školstvo nije steklo tradiciju u Šibeniku za razliku od zanatsko-obrtničke djelatnosti koja je crpila znanja preko državnih tečajeva i majstorskih ispita lokalne Zanatske škole od 1930. godine (Blažević, 2007).

Dodatno se o hortikulturi može reći da je prirodna ljepota našeg podneblja u ranoj fazi merkantilističkog razdoblja prije gotovo više od 200 godina privlačila učenu inozemnu istraživačku klijentelu sklonu spoznaji kulture i prirode neistraženih predjela. Kultura hortikulturne baštine temeljila se na postojećoj baštini kao izvorištu iz bogate tradicije naroda i ljepoti šibenskog krajobraza koja je od kraja 18. stoljeća pod interesom stranih putopisaca. Oni većinom potječu iz malih talijanskih pokrajina i vojvodstava, iz austrijskih zemalja i više njemačkih vojvodstava. O ljepoti grada, a posebno pejsažne prirode svjedoči u svojem putopisu i slavni Alberto Fortis u djelu Viaggio in Dalmazia iz 1774. godine. Kasnije su ovo podneblje slavili autori od kojih za prvu polovicu 19. stoljeća valja spomenuti: Franza Pettera, Heinrich Stieglitza, Johana Georg Kohla i gđu. Idu von Reinsberg-Duringsfeld, posebno u njenom za Šibenik značajnom putopisu, objavljen u knjizi Aus dalmatien objavljenu u Pragu 1857. godine (Pederin, 1989).

Prema kraju 19. stoljeća u pojedinim putopisima ima više podataka o prirodoslovnim vrijednostima Šibenika, uključujući otoke i skradinsko otočje, tok i atrakcije rijeke Krke, kao i šire zaleđe oko grada Drniša. To je bilo vezano s interesom novo osnovanog pomorskog društva Loyd u vezi prometnog povezivanja preko luke Trst na čitavu Dalmaciju. To se vrijeme od početka 50-ih godina 19. stoljeća 
može smatrati kao razdoblje početaka promicanja turističke djelatnosti. Iz toga je razloga i rijeka Krka u interesu hortikulturnih pregalaca već od druge polovice 19. stoljeća. ${ }^{11}$

Spomenuti je da se u među ratnom razdoblju između 1918. i 1941. godine hortikulturi i vrtlarstvu počelo pristupati s planiranom pozornošću. Primjeri su vidljivi oko uređenja pristaništa i ranije oko uređenja okoliša u Zlarinu od 1910. godine, potom uređenja oko restauracije u Tijesnome itd. Podizanja vidilica te uređenja tijeka i obalnih strana rijeke Krke po planovima iz 1917. godine. ${ }^{12}$

Dana 5. ožujka 1941. banska je vlast dozvolila osnivanje nacionalnog parka na rijeci Krki s prijedlozima oko održavanja i zaštite prirodne cjeline. Bilo je to vrijeme novog razumijevanja kulture hedonizma u jeku pojačane želje za otkrivanje nepoznatog u bajkovitim prostorima šibenskog areala ${ }^{13}$. Ratna zbivanja su zaustavila ove dobre namjere, ali je nova koncepcija simbioze komunalnih potreba nakon 1945. godine pomalo utirala prihvaćanje svjetskih recentnih stremljenja u hortikulturnošumarskoj struci. Svoju su realizaciju nalazili u širem obogaćivanju prirodoslovnom baštinom Šibenik i njegovo priobalje otkrivajući nove rezultate primjenom raznolike, slojevite i snažne lokalne tradicije.

\section{Zaključak}

Iz navedenog gradiva vidljivo je da je poljodjelstvo, parkovno uređenje, hortikultura i šumarstvo bilo od izuzetnog značaja za globalnu sliku o gradu Šibeniku. Učinak tih djelatnosti bilo je od presudne važnosti za preobrazbu Šibenika iz ruralnog u urbano središte. Doprinosi ovih djelatnosti kroz iznesene podatke prikazuje obilje zavičajnih podataka iz različitih vremenskih razdoblja, a koje svoju izvornost izvlače iz gradske i težačke sredine i običaja ovog podneblja. Stoga je ovaj kratki prikaz samo dio doprinosa za daljnje proučavanje bogate baštine šibenskog gospodarstva i promicanja simbioze građanske uljudnosti.

\section{Literatura}

\section{Arhivski fondovi i zbirke}

DAŠI, Fond Općinsko upraviteljstvo u Šibeniku (1813.-1918.)

DAŠI, Općinsko upraviteljstvo Šibenik od (1921.-1941.)

DAŠI, Kotarska oblast Šibenik (1921.-1941.)

DAŠI, fond Zbirka Parkovi i hortikultura (19.-20. stoljeće)

\section{Popis literature}

Blažević, M. (2007). Prilog povijesti poljoprivrede šibenskog područja od 1921. do 1941. godine. Radovi Zavoda za povijesne znanosti HAZU u Zadru 49, 645-689.

\footnotetext{
${ }^{11}$ DAŠI, fond Zbirka Parkovi i hortikultura (19.-20. stoljeće)

${ }_{12}$ Privatna Zbirka turističkih prospekata Milivoja Blaževića.

${ }^{13}$ DAŠI, Kotarska oblast Šibenik (1921.-1941.).
} 
Blažević, M. (2011). Zemljišni posjedi u arhivskim dokumentima-katalog izložbe. Državni arhiv u Šibeniku.

Božić-Buzančić, D. (1993). Južna Hrvatska u europskom fiziokratskom pokretu: pokret za obnovu gospodarstva, gospodarske akademije, ogledni vrtovi i poljodjelske škole druge polovice XVIII. I početka XIX. stoljeća. Split: Književni krug.

Defilippis, J. (2006). Promjene u poljoprivredi i selu Dalmacije u posljednjih stotinjak godina. Društvena istraživanja: časopis za opća društvena pitanja 15, 6 (86), 1047-1062.

Dorbić, B., Pamuković, A., Blažević, M. (2014). Prilog poznavanju povijesti hortikulturne i bilinogojstvene edukacije stanovništva šibenskog kotara u razdoblju 1920.-1939. godine. Radovi Zavoda za povijesne znanosti HAZU u Zadru 56, 263-287.

Dorbić, B., Temim, E. (2016). Povijesni pregled razvoja vrtlarstva i krajobraznog uređenja Šibenika i okolice u razdoblju 1885-1945. godine. Annales-Ser. Hist. Sociol 26, 2; 227-246.

Dorbić, B., Pamuković, A., Blažević, M. (2017). Djelovanje kotarskog agronoma Vinka Anzulovića u edukaciji puka šibenskog kotara iz biljne proizvodnje u razdoblju 1921-1940. Annales-Anali za Istrske in Mediteranske Studije-Series Historia et Sociologia 27, 1, 61-80.

Grubišić et al., (ur.). (1976). Zbornik o 900-toj godini grada Šibenika. Muzej grada Šibenika.

Marković, J. (2009). Šibenik u doba modernizacije. Šibenik: Institut za povijest umjetnosti-Zagreb i Gradska knjižnica "Juraj Šižgorić".

Pederin, I. (1989). Njemački putopisi po Dalmaciji. Split: Logos Split.

Peričić, Š-T. (2016). Prinosi povijesti gospodarstva Šibenika i njegova područja do 1940. godine. Gradska knjižnica "Juraj Šižgorić" Šibenik.

Tambača, A. (1998). Vinogradarstvo i vinarstvo šibenskog kraja kroz stoljeća. Šibenik: Matica hrvatska.

Žmegač, A. (2016). Priručnik za Dalmaciju: De Trauxov opis iz 1805. Ars Adriatica, 6, 199-208.

Primljeno: 23. svibnja 2018. godine

Prihvaćeno: 29. lipnja 2018. godine
Received: May 23, 2018

Accepted: June 29, 2018 